\title{
(1⿶)
}

Citation:

Ismail, $\mathrm{N}$ and Woodall, $\mathrm{J}$ and de Viggiani, $\mathrm{N}$ (2019) Using laws to further public health causes: the healthy prisons agenda. Global Health Promotion. ISSN 1757-9759 DOI: https://doi.org/10.1177/1757975918811098

Link to Leeds Beckett Repository record:

https://eprints.leedsbeckett.ac.uk/id/eprint/5317/

Document Version:

Article (Accepted Version)

The aim of the Leeds Beckett Repository is to provide open access to our research, as required by funder policies and permitted by publishers and copyright law.

The Leeds Beckett repository holds a wide range of publications, each of which has been checked for copyright and the relevant embargo period has been applied by the Research Services team.

We operate on a standard take-down policy. If you are the author or publisher of an output and you would like it removed from the repository, please contact us and we will investigate on a case-by-case basis.

Each thesis in the repository has been cleared where necessary by the author for third party copyright. If you would like a thesis to be removed from the repository or believe there is an issue with copyright, please contact us on openaccess@leedsbeckett.ac.uk and we will investigate on a case-by-case basis. 


\section{USING LAWS TO FURTHER PUBLIC HEALTH CAUSES: THE HEALTHY PRISONS AGENDA}

Ismail, N.; Woodall, J. R.; de Viggiani, N.

\section{INTRODUCTION}

In this commentary, we advocate for the use of laws in implementing the Healthy Prisons Agenda. Adopting the whole-prison approach, the Agenda, proposed by the World Health Organization (WHO), aims to reduce health risks among prisoners, recognise prisoners' human rights while maintaining a security regime, ensure the equivalence of prison health services to community health services, and promote health and welfare in prisons (1).

The remainder of this paper is structured as follows. On providing background information about the ever-growing interest in the factors determining prisoner health, along with a discussion of the utility of legal structures in addressing health inequalities in prisons, we proceed to explore how states, building upon the international concordats which they have signed, can safeguard prisoners' right to health care. We then articulate how laws can be used to recognise and strengthen the role of prisons as health-promoting institutions. We conclude by suggesting further evaluation of the proposed framework as part of an iterative, transnational response to address the health needs of prisoners across the world. 


\section{BACKGROUND}

Prisoners are among the most vulnerable and marginalised members of the population worldwide. Globally, about 10.4 million people are held in penal institutions (2). In addition to the overwhelming evidence regarding their physical and mental ailments (3), the female prison population has increased by $50 \%$, which is almost three times higher than the corresponding increase of the male prison population (2). Similarly, older prisoners comprise $13 \%$ of the global prison population, and incarceration both accelerates the ageing process and increases the elderly prison population's risk of chronic health problems (4).

There are opportunities to address the needs of various groups within the global prison population. Laws represent one such mechanism, and can be an ideal tool to support public health agendas. In this respect, evidence is available demonstrating that laws can be meaningfully used to establish a framework to drive behavioural change within a supportive environment (5). Similarly, a statutory foundation can set minimum standards for health services to be recognised and adhered to by the state, its actors, and the population as a whole.

In what follows, using the Healthy Prisons Agenda of the World Health Organization as a lens, we explore how the alignment of laws with the Healthy Prisons Agenda can help address the burgeoning healthcare inequalities within penal institutions. We will explore the possibility of such alignment in the context of legislation at the state level to argue that, within the 194 WHO member states 
that subscribed to the Healthy Prisons Agenda (1), appropriate legislation can create a uniform level of protection for prisoner health worldwide.

\section{USING LEGISLATION TO SAFEGUARD PRISONERS' RIGHT TO HEALTH}

A legislative structure ensures that states fulfil their international obligations with respect to prison rehabilitation. These commitments include Article 12 of the International Covenant on Economic, Social, and Cultural Rights, Principle 9 of the Basic Principles for the Treatment of Prisoners, and the Standard Minimum Rules for the Treatment of Prisoners (the Nelson Mandela Rules). Collectively, they create a duty of care for states to ensure acceptable conditions in prisons, particularly given that prisoners have no alternative but to rely on the authorities to support their health while in detention. Taken together, these obligations provide the prerequisite lever for the obligations under the Healthy Prisons Agenda to be recognised via legislation that reflects the government's commitment to honouring its international obligations regarding prison rehabilitation.

However, despite the permanency of legislative measures, the unstable nature of the international principles underlying them may jeopardise the effectiveness of those measures. The Convention principles are, at best, a vague articulation of state obligations and, at worst, are merely equivocal (6). Similarly, there is no direct link to population health; accordingly, this justification to protect prisoner health is frequently applied in an incremental manner (6). However, opponents to this view have argued that these principles are already entrenched in international obligations and are, at the very least, authoritative interpretations 
that states cannot set aside without a good reason (7). In order to consolidate and realise the rights that emanate from international provisions in a more enduring fashion, a permanent measure, such as legislation, would be urgently needed.

Another factor that can sub-optimise the implementation of the Healthy Prisons Agenda is the inconsistent political interest in ensuring protection for detainees' health. Political debates that pivot around neoliberalism have frequently overplayed individualism rhetoric, while underplaying the role of societal and environmental forces that drive patterns of re-offense (8). This perspective reduces the interventionist role of the state, perpetuates a reductionist and myopic mentality, and reduces the role of health and wellbeing in reducing recidivism (9). Ironically, within the context of the penal environment, this view also requires prisoners to rely solely upon the state for their health and social care needs. To amend the situation, the introduction of legislation concordant with the Healthy Prisons Agenda would make it possible to acknowledge the role of health in reducing re-offense, frame re-offense as a derivative of wider social and environmental factors, and protect prisoner health from political volatility.

Another hurdle is that, in most countries, prison health is overseen by a Ministry of Justice or the Interior (10). In these countries, the implementation of health services in prisons is often undertaken without input from the national health services (10) which creates an unsustainable conflict of interest that endangers prisoner health, and this risk has started to be recognised by some states. Accordingly, the United Kingdom, France, and Norway have pioneered shifting of the healthcare responsibility to a Ministry of Health, and this change is 
reported to have improved access to healthcare interventions in prisons and to better guarantee continuity of care provided by the national health service pre-, during, and post-detention (10). The use of a statutory foundation, along with helping the Agenda survive any potential political volatility threatening its efficacy, can robustly address the potential policy challenges in implementing the Agenda.

\section{USING LEGISLATION TO STRENGTHEN THE STATUS OF PRISONS AS HEALTH-PROMOTING SETTINGS}

Statutory support for the Healthy Prisons Agenda should recognise the role of prisons as health-promoting institutions. In line with the Ottawa Charter (11) and the Sundsvall Statement (12) that emphasise the role of supportive settings in promoting health, prisons are a modifiable determinant of health. This makes it possible, using an upstream approach, to frame the prison health discourse within a salutogenic, holistic, and inclusive model of health (13). We propose that, upon forging the connections with the wider justice sector, legislation can promote the integration of rehabilitation culture into the core mission of penal institutions without endangering security or public safety.

Despite this promise, overcrowding, which afflicts almost a fifth of prisons worldwide (2), may hinder the efficacy of prisons as health-promotion settings. To enhance the effectiveness of the Healthy Prisons Agenda, we propose that statutory instruments should be used to prioritise alternatives to imprisonment, such as community sentences or early release (14). Beyond overcrowding, implementation of the Healthy Prisons Agenda relies on prison governors and 
prison staff. Involving these gatekeepers may seem precarious, as prisons operate under a security and public protection philosophy (8), which contradicts the essential health-promotion principles of personal and collective empowerment. In this respect, legislation may motivate the enlightened leadership of prison governors to engage with a rehabilitation programme-an attitude that may inspire the prison staff to appreciate the value of the Healthy Prisons Agenda. Echoing Ottawa (11) and Sundsvall (12), the education of prison governors and staff should underscore the message that healthpromotion initiatives can coexist with the current security and discipline regime in prisons.

\section{CONCLUSION}

In this commentary, we have proposed that legislation can play a key role in implementing the Healthy Prisons Agenda. Institutionalising the Healthy Prisons Agenda through legislation can address the precariousness of international treaties and strengthen the recognition of prisons as health-promoting institutions. Additionally, such movement will align the states in supporting the recent introduction of Goal 10 of the United Nation's Sustainable Development Goals 2030, which seeks to fulfil the health and social care needs of people in contact with the criminal justice system, including prisons (15).

Despite the nuances required by legislation in support of the Healthy Prisons Agenda, legislation should be further re-evaluated (14). Specifically, a multiscalar implementation across 194 WHO nation states will lay the foundation for meaningful transnational comparisons of the success of legislation in the 
Healthy Prisons Agenda implementation across countries and continents, while simultaneously establishing a feedback loop from these countries back to the WHO as the custodian of the Agenda.

Finally, due to its inherent flexibility regarding the nature of the programme, political climate, and target population, the proposed legal framework can be implemented in other health-promotion agendas. Therefore, we urge a wider research community to examine whether legal theories can be applied to support practical public health initiatives. Doing so will promote the integration of public health and law, strengthen public health programmes, and safeguard public health programmes against future political, economic, and social challenges. 


\section{REFERENCES}

1. World Health Organization [Internet]. Health in Prisons: a WHO Guide to the Essentials in Prison Health; c2007 [cited 2018 June 21]. Available from: http://www.euro.who.int/document/e90174.pdf.

2. Coyle A, Fair H, Jacobson J, Walmsley R. Imprisonment Worldwide: The Current Situation and an Alternative Future. Bristol: Policy Press; 2016.

3. Stürup-Toft S, O'Moore EJ, Plugge EH. Looking behind the bars: emerging health issues for people in prison. Br Med Bull. 2018; 125(1): 15-23.

4. Prison Reform International [Internet]. Global Prison Trends 2017; c2017 [cited 2018 June 21]. Available from: https://cdn.penalreform.org/wpcontent/uploads/2017/05/Global_Prison_Trends-2017-Full-Report-1.pdf.

5. Burris S, Ashe M, Levin D, Penn M, Larkin M. A transdisciplinary approach to public health: the emerging practice of legal epidemiology. Annu Rev of Public Health. 2016; 37: 135-148.

6. Lines $\mathrm{R}$. The right to health of prisoners in international human rights law. Int J Prison Health. 2008; 4: 3-53.

7. van Zyl Smit D, Snacken S. Principles of European Prison Law and Policy: Penology and Human Rights. Oxford: Oxford University Press; 2009.

8. Cavadino M, Dignan J. Penal Systems: A Comparative Approach. London: Sage; 2006.

9. Woodall J, de Viggiani N, Dixey R, South J. Moving prison health promotion along: towards an integrative framework for action to develop 
health promotion and tackle the social determinants of health. Crim Justice Stud. 2010; 27: 114-132.

10. World Health Organization. Good Governance for Prison Health in the 21st Century: A Policy Brief on the Organization of Prison Health. Copenhagen: World Health Organization; 2013.

11. World Health Organization. Ottawa Charter for Health Promotion. Geneva: World Health Organization; 1986.

12. World Health Organization. Supportive environments for health: the Sundsvall Statement. Health Promot Int. 1991; 6: 297-300.

13. Antonovsky A. Health, Stress, and Coping. London: Jossey-Bass; 1979.

14. Ismail N, de Viggiani N. Should we use a direct regulation to implement the Healthy Prisons Agenda in England? A qualitative study among prison key policy makers. J Public Health (Oxf). 2017 Aug 31: 1-8. doi:10.1093/pubmed/fdx116L. PubMed PMID: 28977435.

15. United Nations [Internet]. Sustainable Development Goals: 17 Goals to Transform Our World; c2015 [cited 2018 June 21]. Available from: http://www.un.org/sustainabledevelopment/sustainable-developmentgoals/. 